As a counterpart to the historical exhibit, mentioned above under the name of Sir Napier Shaw, the 'Forecasting' section of the exhibition shows a model illustrating the three-dimensional structure of a warm-sector depression, based upon a depression that crossed the British Isles in January 1946.

In the fourth section, "Weather in our Daily Lives", it has been necessary to select a few topics for illustration from the very considerable range of subjects. Transport-land and air transport, and shipping-are examples of undertakings manifestly affected by the weather, and dependent upon meteorology for their most efficient operation. Other topics illustrated in this section are agriculture (including a model illustrating the effect of a shelter-belt protecting an orchard), water supply, electricity supply (including a model of a projected $100-\mathrm{kW}$. wind generator), climate and house design (including an illustration of an investigation by the Building Research Station of the Department of Scientific and Industrial Research on a group of experimental houses at Abbott's Langley), atmospheric pollution, and civil engineering (this is illustrated by an exhibit dealing with the determination of the fine structure of the local wind, in connexion with the design of the proposed Severn Bridge).

In the fifth section of the exhibition, "Meteorological Research", the following topics are illustrated : eloud physics, turbulence, radiation, upper atmosphere, atmospheric sounding, and synoptic meteorology. Radio, and especially radar, methods of investigation have substantially improved the meteorologist's ability to study cloud processes in situ, and a number of charts and photographs show methods of studying free water in clouds, and the wave-form of lightning discharges. Working demonstrations are provided of a method of determining drop-size distribution in a cloud or in rainfall, and of the growth or decay of a hygroscopic particle when subjected to an atmosphere of variable humidity. A display of very wide appeal is a cloud chamber in which periodical demonstrations are given of the principle of the artificial production of rain from a cloud containing supercooled water droplets, by seeding with solid carbon dioxide.

The exhibit dealing with turbulence is concerned with turbulence occurring within a few feet of the ground, and shows a variety of pieces of apparatus developed for measuring the phenomenon.

Radiation research is represented by ozone spectrophotometry. Dr. G. M. B. Dobson's original instrument is exhibited, together with drawings and photographs of the modern commercial instrument developed from it. Accompanying the apparatus are charts showing the correlation of ozone content with weather.

In studies of the upper atmosphere, radio investigations of the ionosphere have confirmed the existence of high wind velocities at that level, which had already been deduced from the examination of luminous night clouds and of the polar aurora. The evidence for these winds is displayed, with a working model explaining how the notion of a wind at ionospheric level may be dedured from observations of radio fading, and its speed and direction measured.

The general title "Atmospheric Sounding" has been used to describe a group of exhibits illustrating research into instruments for various observations : the frost-point hygrometer, as developed to measure frost-point temperatures as low as $-80^{\circ} \mathrm{C}$.; an airborne radar 'transponder' which will enable the range of radar wind-finding equipment to be increased to about a hundred miles; and a photoelectric visibility meter.

Research in synoptic meteorology is illustrated by two exhibits : one is a series of weather-charts representing research now being pursued in Great Britain to extend the period of useful forecasting; and the other shows how observations of wind-finding balloons may be applied to measuring large-scale vertical motions in the atmosphere.

A collection of current books on meteorology and weather is included in the exhibition.

D. Chilton

\section{HIGHER TECHNOLOGICAL EDUCATION IN GREAT BRITAIN}

A SPECIAL conference on higher technological education in Great Britain was held in the rooms of the Royal Society on the afternoon of March 27, under the chairmanship of Sir Henry Tizard. The conference had been arranged by the Advisory Council on Scientific Policy with the view of bringing together those primarily interested in future policy for the organisation of higher technological education in the United Kingdom. Those present included the president and several fellows of the Royal Society, representatives of the Ministry of Education, the University Grants Committee, the Advisory Council on Scientific Policy and university departments of applied science, together with a number of the contributors to recent correspondence in The Times and others who had shown a special interest in the sub. ject. Mr. M. J. Kelly, executive vice-president of the Bell Telephone Laboratories in New York, also attended by invitation and gave a short address.

Sir Robert Robinson, president of the Royal Society, in opening the proceedings, said that he thought it was most valuable to have a conference of the sort which had been organised with the view of bringing together advocates of the different policies which had recently been supported. He suspected that some of the differences were not so deep as they might at first sight appear to be. Sir Henry Tizard said that it is a matter of common agreement that it is vital to the interests of Great Britain to increase rapidly the output of those who could apply the fundamental principles of science. Discussions at meetings of the Advisory Council on Scientific Policy and elsewhere had shown an unfortunate divergence of opinion about how this could best be done, and he feared that if agreement were not reached, effective action of any sort might be delayed.

The first speaker to give his views was Lord Cherwell, who said that the vital need of Great Britain after two costly wars is to increase exports, since otherwise a disastrous fall in the standard of living would occur. For this purpose the important thing is to translate scientific knowledge into application. So far there is general agreement; the present controversy turns on the question whether the technical education required can be best provided by university departments of applied science or by independent institutes of higher technology. $\mathrm{He}$ believes that the decisive reason why the universities would not be able to do the work effectively is that they could not, without changing their whole character, 
undertake an expansion of the order necessary to educate the numbers of students who should receive education in higher technology. Apart from this, higher technological education could not be carried out effectively or economically unless it is given in very large institutions attended by some two to four thousand students. Such numbers could not be absorbed by any existing university in Great Britain, except perhaps London, and he therefore thinks it desirable to create a number of technical universities or colleges of the calibre of the Massachusetts Institute of Technology or the Zurich Technical High School. The cost of building such an institute would probably run to $\mathfrak{1 4 - 5}$ million.

Prof. J. F. Baker, professor of engineering in the University of Cambridge, said that the qualifications of a technologist in the strict sense are exacting. $\mathrm{He}$ requires a sound grounding in the fundamental sciences ; he has to be a considerable mathematician ; and he has to undergo the discipline of dealing with particular problems in detail and judging what is a practicable solution. He also requires a certain knowledge of methods and processes in actual use if he is to collaborate successfully with the technician. Such of these qualifications as cannot be acquired at a university are best obtained through practical experience in industry. Prof. Baker said that he sees no roason why facilities for higher technological education should not be considerably expanded at such centres as the Imperial College of Science and Technology, London, and the University of Birmingham ; but if this policy is to be successful he believes a new attitude would have to be adopted to engineering technology. In Great Britain such technology is greatly prejudiced by the prevailing tradition that practical techniques are not the business of universities, whereas in the United States the opposite attitude is universally adopted. Prof. Baker agreed that there may be something to say for a technical university if it could be provided ready-made; but he felt that the cost in money and man-power of building it and staffing it adequately would be prohibitive. It would take yoars to put such an institution into running order, and this could only be done at the expense of existing institutions which, however imperfect, are already producing students and research, and are rapidly achieving a higher level of efficiency by the development of postgraduate courses.

Mr. H. Richardson, principal of the Technical College, Bradford, made a plea for developing higher technological education in some of the major technical colleges. $\mathrm{He}$ recalled that the Percy Report recommended the upgrading of some of these colleges for this purpose, and said that the saving of material and labour which would be effected by this policy is a vital consideration at the present time. Some of the local colleges are giving more and more of their attention to higher technology and a few have reached the standards of the university colleges. The main difficulty which faces them in carrying out this work, he said, is the fact that they are governed by the local education authorities and financed largely from the local rates, so that they cannot offer the same terms of service to their staffs as universities. With a new system of financing and government, there is no reason why some of these colleges should not discharge the functions of the special institutes of higher technology which Lord Cherwell advocated.

Prof. J. Kendall, professor of chemistry in the University of Edinburgh, believes that there is undue pessimism about technological education in the United Kingdom. His own experience is that the best technological students in Britain are fully equal to the best in the United States or on the Continent ; but it has to be recognized that the American institutions are financed on a much more lavish scale. With more financial support the Imperial College could embark on a large-scale development. In some universities the problem has been solved by developing a close relationship between the university and the leading technical college in the area. A good example is the working arrangement made between the University of Edinburgh and the Heriot-Watt College. Much could be done to promote higher technological education if the work of universities and technical colleges were better correlated.

In the subsequent discussion, Sir John Cockcroft supported the view that special institutes of higher technology are necessary. He agreed that the simplest way of creating them, if it were practicable, would be to raise the status of some of the technical colleges by changing their method of government and finance.

Sir Roderic Hill, rector of the Imperial College of Science and Technology, said that the Colloge could increase its present rate of expansion very considerably if necessary ; but he thought it would be in the best interest of the College not to do this.

Prof. A. R. Todd, professor of chemistry in the University of Cambridge, expressed doubts whether the universities could organise the desirable expansion in higher technological education without becoming lop-sided.

Dr. A. E. Trueman, chairman of the University Grants Committee, said that there is no evidence that the demand of industry for higher technologists will be greater than the universities can meet. It is, no doubt, a distinct question whether industry ought to demand a greater number of higher technologists ; but he believes much harm would be done if the expansion were such that higher technology became a field of unemployment.

Advantage was taken of the presence in Great Britain of Mr. M. J. Kelly, executive vice-president of the Bell Telephone Laboratories, New York, to obtain his views on technological education. He said that British industry would benefit from an increased number of higher technologists, and the only question in doubt is how this increase could be most quickly achieved. In his opinion, universities are definitely less satisfactory for the conduct of higher technological education than special institutes like the Massachusetts and California Institutes of Technology. In universities, there tends to be too much separation between pure science and engineering; but in these special institutes the two subjects are closely associated. Once the supply of higher technologists in Britain is appreciably increased, it would be possible to appoint more of them to leading executive positions in industry, a practice from which American industry has greatly benefited.

Mr. G. J. Nash, of the Appointments Department of the Ministry of Labour, said that his Department's statistics support Dr. Trueman's view that the de. mand for higher technologists by British industry does not greatly exceed the present supply, and shows no signs of increasing substantially.

Sir Lawrence Bragg expressed his belief that the proper work of the universities would be adversely affected if they were given the responsibility of increasing the output of higher technologists. On the other hand, he felt that technical colleges under local 
control would not provide a satisfactory foundation for the work. He therefore supported the view that the best place for the education of a higher technologist is a special institute of higher technology, and he hoped that the experiment of setting up at least one such institute in the United Kingdom would be undertaken. Prof. S. Zuckerman said he agreed that at least one institute of higher technology should be set up. $\mathrm{He}$ had been greatly impressed by the excellence of the research as well as the teaching work which he had seen at the California Institute of Technology, and thought that a college of the same general sort would be of great value to the United Kingdom.

Prof. R. S. Hutton said that a study of the history of the German technical high schools showed that it takes about twenty years to get these into proper working order and establish their reputation. Thus if a demand for such colleges is anticipated in the future, it is important to proceed with the plans quickly. He himself has no doubt that the qualifications demanded of the higher technologist are most successfully acquired in such institutions.

Prof. A. R. J. P. Ubbelohde said that the increase in technologists is required primarily in the top grades, and this constitutes a basic difficulty in utilizing local technical colleges for their training.

At the conclusion of the proceedings, Sir Henry Tizard thanked those who had contributed to the discussion, and said that the Advisory Council on Scientific Policy would give the matter further consideration in the light of the views which had been expressed.

\section{OBITUARIES}

\section{Mr. A. J. Wilmott}

Alfred James Wrimotr died suddenly at South Kensington on January 26. He had given a students' lecture on "Geographical Distribution and Classification" at the Linnean Society the evening before.

He was born at Tottenham on December 31, 1888 ; but his parents soon moved to Cambridge, when his father, Alfred John Wilmott, was appointed lecturer in history and classics at Homerton Training College.

Young Wilmott soon showed that faculty of rapidly acquiring knowledge which lasted throughout his life. He gained an entrance to the new Cambridge County School, and from there a scholarship to St. John's College in 1906. As he was the first pupil of the School to go up to the University, he had been invited to speak at the jubilee celebrations to be held in July next, and had intended to hurry back from the International Botanical Congress at Stockholm to do so.

He early became interested in outdoor natural history, being encouraged by his father, who was a man of wide culture. At first entomology most attracted him ; but at school Dr. Marion Dawson, who was biology mistress, turned his attention to her own special branch-botany. When he went up to the University his knowledge of field botany was much greater than was then usual among undergraduates.

At the University he obtained a first in both parts of the Natural Sciences Tripos, and was awarded a Hutchinson Scholarship at St. John's and the Frank Smart Prize. Like most who then did botanical research at Cambridge he was attracted by physiology, and worked under Dr. F. F. Blackman. He devised a glass 'bubbler' which, when fitted on to the cut stem of a submerged water plant, caused the liberated bubbles to be of a definite and constant size: the bubbles were delivered directly into a cup so that they did not enter into direct contact with the solutions that were being used. My own feeling is that Wilmott would have made a mark in plant physiology, for he had an aptitude for devising ways and means, and his fertile and inaginative mind would have benefited by precise and exact chemical and physical answers to his philosophizing.

Wilmott's knowledge of the flora of Cambridge brought him into contact with C. E. Moss, who had been appointed curator of the Herbarium in 1908, and who gave stimulating lectures on botanical taxonomy. When the Department of Botany, British Museum (Natural History), announced the impending appointment of an additional assistant to work at British and European plants, Moss suggested that he should become a candidate. Competition in those days was by examination, and Wilmott was successful, but did not take up his duties until May 1911. When he arrived, the European room had boen built and a fow cabinets installed. His first task was to extract the European plants from the general collections (the British plants had been segregated by Robert Brown in 1849). For the whole of his Museum career Wilmott was engaged in incorporating collections-an enormous task still far from completion, for there have been constant large and important accessions which have made the British and European Herbarium without a rival. It was his claim that his arrangement of unincorporated material ensured that every specimen was available for consultation. Whatever future rearrangements may have to be made because of expansion, Wilmott's curatorial work, extensive and precise, will remain as a solid foundation.

It is more difficult to assess Wilmott's scientific status. It cannot be gainsaid that he greatly influenced those studying British plants by his ever-ready help in the herbarium, by his insistence on accuracy-an insistence often most strongly expressed -by his wide knowledge of the habitats of British plants and the factors concerned in their distribution, and by his extensive acquaintance with the European flora. He was much in evidence in the affairs of the Botanical Society of the British Isles, sparing no pains in furthering its objects : he was in many matters the final authority, and this appreciation did much to stimulate him.

Wilmott was a man of ideas and of schemes. Unfortunately he did not possess the faculty of pressing on regardless of attractive side-lines, and became enmeshed in many of these.

He contributed the account of the genus Atriplex to the Cambridge Flora. He acted as editor to the tenth edition of Babington's "Manual of British Botany." (1922) at Mrs. Babington's request and provided an appendix to include the most important additions since Babington's death. For the most part his publications consist of short papers, the principal ones dealing with marsh orchids, Sorbus, Alchemilla, Rhinanthus and Salicornia; he had been engaged on a monograph of the British species of Salicornia for many years and it was nearing completion.

He was a convinced believer in the survival of a relict glacial flora and became the chief British exponent of the theory.

Nomenclature had an abiding attraction for him throughout his career, and his clear and logical treat- 